\title{
Model Pembelajaran Kooperatif Tipe Jigsaw Berbantuan Mind Mapping Berpengaruh terhadap Keterampilan Berbicara
}

\author{
Deswinta Febiyanti ${ }^{1}$, I Made Citra Wibawa ${ }^{2}$, Ni Wayan Arini ${ }^{3}$ \\ ${ }^{123}$ Prodi Pendidikan Guru Sekolah Dasar \\ Universitas Pendidikan Ganesha, Singaraja, Indonesia
}

e-mail: febideswinta@gmail.com, imadecitra.wibawa@undiksha.ac.id, wayanarini@yahoo.co.id

\begin{abstract}
Abstrak
Penelitian ini bertujuan untuk mengetahui pengaruh model pembelajaran kooperatif tipe jigsaw berbantuan mind mapping terhadap keterampilan berbicara siswa kelas IV SD. Jenis penelitian ini merupakan eksperimen semu dengan rancangan nonequivalent post-test only control group design. Dalam penelitian ini jumlah populasinya adalah 176 siswa, sedangkan sampel dalam penelitian ini berjumlah 76 siswa yang ditentukan melalui teknik random sampling. Keterampilan berbicara adalah data dari penelitian ini yang dikumpulkan menggunakan metode non tes dengan teknik unjuk kerja atau performance. Data keterampilan berbicara diuji dengan menggunakan uji statistik deskriptif dan inferensial. Hasil yang diperoleh dari pengujian menunjukkan model kooperatif tipe jigsaw dengan bantuan mind mapping memiliki pengaruh terhadap keterampilan berbicara siswa kelas IV SD (thitung $=2,971>t_{\text {tabel }}=1,6657$ ). Berdasarkan hasil temuan tersebut, dapat disimpulkan bahwa model pembelajaran kooperatif tipe jigsaw berbantuan mind mapping berpengaruh terhadap keterampilan berbicara siswa kelas IV. Maka dari itu masalah adanya kesenjangan antara harapan penerapan Kurikulum 2013 dengan fakta di lapangan mengenai rendahnya keterampilan berbicara siswa kelas IV telah teratasi dengan penerapan model pembelajaran kooperatif tipe jigsaw berbantuan mind mapping.
\end{abstract}

Kata kunci: Jigsaw, mind mapping, keterampilan berbicara

\begin{abstract}
The objectives of this study is to investigate the impact of jigsaw as a cooperative learning model supported by mind mapping on the speaking skills of fourth grade elementary school students in Cluster VI. This research was a quasi-experimental research using only control group design following a nonequivalent post-test. The population in this study was 176 students, While this study sampled 76 students who were determined using random sampling technique. A non-test method with performance technique was used to collect data on speaking skills. Data on speaking capacity was analyzed using descriptive and inferential statistics. The findings of this study show that jigsaw as a cooperative learning model has a major impact in speaking skills of the fourth grade elementary school students in Cluster VI. (tcount $=2,971>t_{\text {table }}=1,6657$ ). Based on the results, it can be concluded that jigsaw as a cooperative learning model, assisted with mind mapping, affects the speaking skill of fourth grade elementary school students.
\end{abstract}

Keywords: Jigsaw, mind mapping, speaking skill

\footnotetext{
*Corresponding author.

Received 20 April 2020, Accepted 20 Juni 2020; Available online 5 Juli 2020 (C) 2020 MI All Rights Reserved
} 


\section{Pendahuluan}

Sekolah Dasar saat ini menerapkan Kurikulum 2013 sebagai acuan metode dan bahan ajar di sekolah. Kurikulum 2013 sendiri merupakan kurikulum yang dibentuk berdasarkan tujuan agar proses pembelajaran di sekolah dapat menjadi media untuk memberikan bekal dan persiapan yang tepat bagi generasi penerus bangsa, sehingga nantinya dapat menjalani hidup yang baik secara iman, produktivitas, kreativitas, inovatif, dan afektif dalam kehidupannya. Baik sebagai pribadi maupun warga negara, serta dapat berkontribusi di masyarakat, bangsa, negara, dan dunia (Peraturan Menteri Pendidikan dan Kebudayaan RI Nomor 67 Tahun 2013.). Selain itu, diharapkan pula bahwa tujuan mulia dari penerapan Kurikulum 2013 dapat dicapai secara optimal dengan menggunakan pendekatan saintifik.

Terdapat beberapa tujuan utama dari Kurikulum 2013, salah satunya adalah mempersiapkan generasi Indonesia yang dapat berkontribusi dalam kehidupan masyarakat secara umum, dalam pencapaiannya kemampuan berkomunikasi akan sangat berpengaruh, sehingga keterampilan berbicara menjadi penting untuk diperhatikan agar tujuan tersebut tercapai. Kemampuan berbicara akan sangat berpengaruh pada komunikasi dan interaksi seseorang, terutama di kehidupan sehari-hari. Hal tersebut dikarenakan dengan memiliki keterampilan berbicara seseorang akan mudah untuk menyampaikan gagasan maupun idenya untuk menjalin suatu hubungan baik dengan sesama orang di lingkungan dan dapat membantu seseorang untuk berkontribusi pada kehidupan bermasyarakat. Keterampilan berbicara juga tercermin pada pembelajaran abad 21 yang mengharuskan seluruh siswa menguasai atau memiliki empat keterampilan dalam proses pembelajaran yang disebut dengan indikator 4C. Indikator 4C yang dimaksud terdiri dari keterampilan critical thinking, communication, collaboration, dan creativity (Sulistyaningrum, dkk., 2019).

Mahendra, 2019) menyatakan bahwa communication (komunikasi) merupakan keahlian yang tidak dapat dihindari dan harus dimiliki oleh manusia sebagai makhluk sosial, manusia membutuhkan untuk tetap berkomunikasi sebagai bentuk interaksi dengan sesamanya. Interaksi dengan menggunakan komunikasi dapat dilakukan secara lisan maupun non lisan (tulisan, bahasa tubuh, dan sebagainya). Bentuk komunikasi utama yang dilakukan adalah komunikasi lisan yang merupakan bentuk implementasi dari keterampilan berbicara yang berdasarkan pada tingkat kemampuan seseorang untuk berbicara secara jelas, baik dan benar. Sehingga pesan yang dibicarakan atau dikomunikasikan mampu diterima dengan baik oleh pendengar. Maka dari itu, diharapkan siswa memiliki keterampilan berbicara yang baik agar mampu berinteraksi di lingkungan keluarga maupun sekolah dan masyarakat.

Namun adanya kesenjangan antara harapan penerapan Kurikulum 2013 dengan fakta di lapangan yang ditunjukkan dengan hasil wawancara pada 25 Oktober 2019 hingga 30 Oktober 2019 dengan masing-masing guru yang mengajar di kelas IV, diperoleh informasi keterampilan berbicara Bahasa Indonesia siswa masih rendah. Bukti lain dari rendahnya kemampuan berbicara juga terlihat dari proses pembelajaran, masih sangat sedikit siswa yang mampu menyampaikan pendapatnya dengan baik ketika selesai diberikan tugas atau ketika ditanyakan mengenai penyelesaian sebuah masalah oleh guru. Siswa masih banyak yang cenderung menunggu guru untuk menjelaskan.

Hasil wawancara tersebut didukung oleh hasil observasi penulis pada tanggal 31 Oktober 2019 hingga 2 November 2019, terlihat bahwa metode mengajar dengan metode ceramah masih banyak digunakan oleh para guru saat mengajar di kelas. Hal tersebut menunjukkan masih kurangnya kegiatan diskusi antar siswa dan guru. Selain itu, dalam pembelajaran hanya memanfaatkan buku tema serta papan tulis saja untuk membantu proses pembelajaran. Guru hanya terpusat pada pemberian materi dengan cara menjelaskan langsung seluruh materi pembelajaran kepada siswa kemudian dilanjutkan dengan penugasan secara individu. Kemudian, ketika siswa mendapat kesempatan bertanya tentang materi yang telah dibahas sebelumnya pada akhir proses belajar, tidak banyak siswa yang mau bertanya. Hal lain juga cukup memprihatinkan adalah terdapat satu kelas IV yang siswa-siswinya tidak mampu untuk menyampaikan gagasannya atau bertanya kepada guru ketika diberikan kesempatan untuk bertanya atau berbicara. Hasil observasi tersebut juga 
didukung dengan pencatatan dokumen mengenai nilai keterampilan berbicara kelas IV yang ditunjukkan pada Tabel 1.

Tabel 1

Rata-rata Nilai Keterampilan Berbicara Siswa SD Kelas IV

\begin{tabular}{|c|c|c|c|c|c|c|c|c|}
\hline \multirow{2}{*}{ No } & \multirow{2}{*}{$\begin{array}{l}\text { Nama } \\
\text { Sekolah }\end{array}$} & \multirow{2}{*}{$\begin{array}{c}\text { Kela } \\
\mathbf{s}\end{array}$} & \multirow{2}{*}{$\begin{array}{l}\text { Juml } \\
\text { ah } \\
\text { Siswa }\end{array}$} & \multirow[t]{2}{*}{ KKM } & \multicolumn{2}{|c|}{$\begin{array}{c}\text { Siswa yang } \\
\text { Mencapai KKM }\end{array}$} & \multicolumn{2}{|c|}{$\begin{array}{c}\text { Siswa yang Belum } \\
\text { Mencapai KKM }\end{array}$} \\
\hline & & & & & Jumlah & $\%$ & Jumlah & $\%$ \\
\hline 1. & $\begin{array}{c}\text { SDN 1 } \\
\text { Kerobokan }\end{array}$ & IV & 27 & 70 & 22 & 81,5 & 5 & 18,5 \\
\hline \multirow[t]{2}{*}{2} & \multirow[t]{2}{*}{ SDN 1 Sangsit } & IV A & 40 & 77 & 23 & 57,5 & 17 & 42,5 \\
\hline & & IV B & 41 & 77 & 21 & 51,2 & 20 & 48,8 \\
\hline 3. & SDN 4 Sangsit & IV & 22 & 68 & 13 & 59,1 & 9 & 40,9 \\
\hline 4. & SDN 7 Sangsit & IV & 10 & 62 & 7 & 70,0 & 3 & 30,0 \\
\hline 5. & SDN 8 Sangsit & IV & 36 & 71 & 22 & 61,1 & 14 & 38,9 \\
\hline & Jumlah & & 176 & 425 & 108 & 61,4 & 68 & 38,6 \\
\hline
\end{tabular}

Berdasarkan hasil pencatatan dokumen yang telah dilakukan, dapat dilihat persentase siswa yang mampu berada pada standar KKM yaitu di SDN 1 Kerobokan sebesar 81,5\%, di SDN 1 Sangsit Kelas IV A sebesar 57,5\%, di SDN 1 Sangsit Kelas IV B sebesar 51,2\%, di SDN 4 Sangsit sebesar 59,1\%, di SDN 7 Sangsit sebesar 70\%, dan di SDN 8 Sangsit sebesar $61,1 \%$. Acuan kelulusan belajar secara umum adalah apabila $85 \%$ dari siswa telah memenuhi standar KKM. Dari persentase tersebut, secara klasikal seluruh kelas IV di SD tersebut masih belum mencapai ketuntasan keterampilan berbicara secara umum karena hasil kelulusan keterampilan berbicara secara klasikalnya masih di bawah $85 \%$.

Terdapat fakta lain mengenai rendahnya keterampilan berbicara yaitu, terbukti dengan tingkat literasi siswa di Indonesia yang masih berada jauh di bawah standar dari OECD (Organisation for Economic Co-operation and Development), yaitu 371 dengan standar skor OECD adalah 487 (Indriani, 2019). Hasil tersebut diperoleh dari Programme International for Student Assesment (PISA) pada tahun 2018. Hasil PISA tersebut menunjukkan kemampuan literasi membaca siswa Indonesia masih jauh di bawah dibandingkan dengan negara lain. Tidak hanya itu, hasil survei UNESCO tahun 2012 terkait dengan literasi masyarakat Indonesia yaitu 0,001 persen yang artinya dari 1000 masyarakat hanya 1 yang memiliki literasi yang baik (P. A. P. Sari, 2020). Fakta selanjutnya adalah hasil PIRLS (Progress in International Reading Literacy Study) tahun 2011 menunjukkan literasi siswa SD di Indonesia berada pada peringkat 45 dari 48 negara peserta (Septiana \& Ibrohim, 2020). Literasi membaca sangat penting dimiliki oleh semua orang, khususnya siswa sebagai generasi penerus bangsa. Hal tersebut didukung oleh Irianto \& Febrianti (2017) dengan penjelasan bahwa selain dapat memperoleh ilmu pengetahuan, siswa juga dapat menangani persoalan dan mendapatkan petunjuk berupa pengalaman yang dapat menjadi acuan suatu saat nanti melalui kemampuan literasi. Literasi membaca yang dimiliki siswa sangat erat kaitannya dengan keterampilan berbicara. Dengan kemampuan literasi membaca, siswa mendapatkan pengalaman dan pengetahuan baru yang dapat diimplementasikan ke dalam kehidupannya melalui keterampilan berbicara yang dimilikinya. Selanjutnya, Satriani, dkk. (2019) menyampaikan bahwa UNESCO mendeklarasikan pelaksanaan literasi di sekolah dengan salah satu kegiatannya adalah kemampuan untuk mengomunikasikan informasi untuk mengatasi berbagai persoalan, kegiatan tersebut bertujuan untuk meningkatkan kualitas kemampuan berbicara. Mengacu pada fakta tersebut, kemampuan atau keterampilan berbicara siswa masih dikatakan rendah.

Untuk mengatasi keadaan tersebut, maka diperlukan upaya agar dapat meningkatkan keterampilan berbicara, karena keterampilan berbicara termasuk ke dalam aspek keterampilan dalam Bahasa Indonesia yang wajib dimiliki oleh seorang siswa. Berbicara 
adalah aspek keahlian berbahasa yang bersifat produktif (Harsini, 2017). Berdasarkan pendapat tersebut, berbicara dapat digunakan dalam membantu kehidupan manusia karena berfungsi sebagai alat atau media untuk berkomunikasi sebagai salah satu cara berinteraksi dengan sesama. Aprinawati, 2017 menjelaskan, kemampuan berbicara ialah kecakapan seseorang dalam mengeluarkan ucapan atau mengatakan suatu kalimat-kalimat dengan maksud untuk memberikan penjelasan mengenai ide, gagasan, dan pola pikir yang telah disesuaikan dengan kebutuhan dari pendengar sehingga dapat diterima dengan baik oleh pendengar. Maka dari itu dapat ditarik simpulan, kemampuan berbicara adalah keahlian untuk mengungkapkan hasil pemikiran, ide maupun gagasannya kepada orang lain.

Setidaknya terdapat dua faktor yang dapat mempengaruhi tingkat keterampilan berbicara siswa berdasarkan pada penjelasan dari Rezeki, dkk. (2019), yaitu faktor eksternal (lingkungan keluarga dan masyarakat) dan internal yang berasal dari metode dan media pembelajaran. Faktor eksternal merupakan penggunaan bahasa di lingkungan keluarga dan masyarakat dapat mempengaruhi keterampilan berbicara bahasa Indonesia siswa, karena banyak siswa yang masih menggunakan bahasa daerahnya masing-masing dalam berkomunikasi di sekolah. Sedangkan faktor internal yang terdiri dari metode dan media pembelajaran juga dapat mempengaruhi keterampilan berbicara siswa. Pendidik harus menguasai serta memiliki keahlian dalam mengemas pembelajaran, pendidik diizinkan menggunakan metode, media, dan model pembelajaran sehingga mampu mengatur proses pembelajaran dengan tujuan meningkatkan respon dari siswa, sehingga tujuan dari proses belajar mengajar tersebut dapat tercapai secara optimal.

Rendahnya keterampilan berbicara dapat ditingkatkan dengan penggunaan model pembelajaran kooperatif tipe jigsaw berbantuan mind mapping saat proses pembelajaran. Karena dalam penerapannya, model pembelajaran kooperatif tipe jigsaw lebih didominasikan dengan kegiatan diskusi yang akan menciptakan interaksi-interaksi antar siswa maupun antar siswa dan guru sehingga kemampuan berbicara siswa pun akan semakin terlatih. Selanjutnya, model pembelajaran kooperatif tipe jigsaw dikolaborasikan dengan penggunaan media mind mapping akan semakin melatih keterampilan berbicara siswa, karena penggunaan mind mapping yang memuat gambar-gambar mampu merangsang siswa untuk mengeluarkan ucapan-ucapan yang ada di dalam pikirannya.

Hambali (2017) menyampaikan, pembelajaran kooperatif merupakan proses belajar mengajar dengan menggunakan pendekatan yang berpusat pada kelompok kecil untuk bekerja sama sehingga dapat mencapai tujuan dari proses pembelajaran tersebut. Pembelajaran yang kooperatif akan mengaktifkan suasana dalam kegiatan pembelajaran karena rasa kerja sama dari siswa akan dapat ditingkatkan, selain itu rasa tanggung jawab siswa juga dapat ditingkatkan untuk mengerjakan sesuatu di kelompok kecil tersebut. Selain itu, Nugraha, dkk. (2016) juga menjelaskan bahwa pembelajaran kooperatif adalah paradigma istruksional yang memanfaatkan proses kerjasama yang terjadi dalam kelompokkelompok kecil yang telah dibuat, oleh karena itu tujuan dari pembelajaran tercapai secara lebih optimal. Model kooperatif lebih mengutamakan belajar secara berkelompok kecil untuk mendiskusikan materi pembelajaran, melalui model pembelajaran kooperatif siswa mendapat dampak positif yaitu mampu berinteraksi dan bekerja sama sehingga tercapainya tujuan pembelajaran. Hal tersebut sependapat dengan Karacop (2017) yang menekankan bahwa proses belajar mengajar yang kooperatif memiliki dampak positif pada prestasi akademik siswa dan pengembangan keterampilan sosial.

Model pembelajaran kooperatif tipe jigsaw diterapkan dengan cara mengarahkan siswa untuk membentuk kelompok-kelompok kecil yang kemudian anggota dari kelompok tersebut diberikan materi yang berbeda dengan anggota lainnya, sehingga nantinya diharapkan setiap anggota kelompok dapat membantu anggota lainnya untuk memahami dan menguasai materi yang digunakan. Hal tersebut akan membuat anggota kelompok berlatih bertanggung jawab untuk menguasai materi yang diberikan kepadanya sehingga dapat menjelaskan ke anggota kelompok lainnya nantinya. Kamaruddin \& Yusoff (2019) juga sependapat dengan hal tersebut, ditunjukkan dengan pernyataan bahwa jigsaw mampu membuat siswa mahir dalam suatu materi yang mereka pelajari. Selanjutnya, Munte (2019) menyampaikan bahwa jigsaw adalah model yang mengajarkan siswa melalui teman sebaya 
sehingga dapat menciptakan semangat kerja sama dan menumbuhkan tanggung jawab. Model tersebut mampu menjadi tempat siswa untuk berlatih memecahkan suatu permasalahan maupun mempelajari suatu materi dengan bekerja sama melalui diskusi kelompok bersama teman sebayanya dan menumbuhkan rasa tanggung jawab kepada siswa untuk dapat memahami materi yang disampaikan atau diajarkan kepada temannya agar teman yang mendengarkannya mengerti maksud dari materi yang disampaikannya.

Keunggulan dari model pembelajaran kooperatif tipe jigsaw adalah siswa menjadi lebih berani dan aktif dalam memberikan ide atau gagasan, selain itu mereka dapat berinteraksi sosial dan bekomunikasi lebih dekat dengan sesama temannya, serta siswa memiliki tanggung jawab secara individual (Trisianawati, dkk., 2016). Penerapan model tersebut saat pembelajaran dapat mengembangkan hubungan antar siswa yang memiliki kemampuan berbeda melalui diskusi kelompok kecil. Dengan berdiskusi, secara langsung siswa telah membina suatu hubungan komunikasi dengan siswa yang lain, keaktifan siswa dapat meningkat saat proses pembelajaran karena siswa secara tidak langsung telah berkompetisi mencapai prestasi sebaik mungkin dengan mengemukakan pendapat yang sebaik-baiknya mengenai materi yang dibahas. Selain keaktifan siswa meningkat, terdapat juga interaksi sosial siswa dengan temannya melalui kegiatan diskusi kelompok kecil, dan menumbuhkan kreativitas serta tanggung jawab siwa untuk menguasai suatu materi pembelajaran.

Model kooperatif tipe jigsaw akan menjadi semakin efektif jika dipadukan dengan menggunakan media pembelajaran. Penggunaan media dalam suatu kegiatan pembelajaran dapat membantu memperjelas pengajaran atau penyampaian pesan serta materi yang sedang dibahas. Selain itu, juga mampu meningkatkan motivasi serta keinginan kepada siswa untuk ikut aktif dalam proses belajar. Media pembelajaran yang cocok dipadukan bersama model tersebut salah satunya adalah mind mapping yang merupakan alat berfikir yang bertujuan mengingat suatu materi dengan membuat kode, simbol, gambar, dan warna yang saling berhubungan (Munawaroh, dkk., 2019). Selain itu, mind mapping juga dapat meningkatkan ketertarikan siswa akan materi yang diberikan saat proses belajar mengajar berlangsung. Kartika, dkk. (2017) juga menjelaskan bahwa dengan penggunaan mind maping, akan mempermudah memahami materi pembelajaran karena dapat dibuat dalam bentuk catatan kreatif. Mind mapping juga dapat menumbuhkan rasa ingin tahu siswa karena di dalamnya memuat gambar maupun bentuk-bentuk dengan pokok-pokok materi. Daya tarik lainnya adalah dikarenakan tidak semua materi yang dipelajari dituliskan dalam mind mapping, sehingga siswa menjadi memiliki ketertarikan yang lebih untuk mengetahui materi yang dibuat dalam bentuk mind mapping tersebut.

Proses pembelajaran menggunakan model pembalajaran kooperatif tipe jigsaw dengan bantuan media mind mapping memiliki sintaks yang harus dilakukan, yaitu: (1) persiapan, (2) penjelasan materi, (3) pembentukan kelompok asal, (4) pembentukan kelompok ahli, (5) diskusi kelompok ahli, (6) diskusi kelompok asal sekaligus pembuatan mind mapping, (7) presentasi, (8) evaluasi, (9) penutup (Kurniasih \& Sani, 2014). Penerapan model pembelajaran kooperatif tipe jigsaw dengan bantuan media mind mapping tersebut mampu mempengaruhi tingkat kemampuan berbicara pada siswa. Dari penjelasan tersebut, tujuan penelitian ini ialah mengetahui pengaruh model pembelajaran kooperatif tipe jigsaw dengan bantuan mind mapping terhadap keterampilan berbicara siswa kelas IV.

\section{Metode}

Penelitian ini dilaksanakan dengan rentang waktu semester genap yaitu pada bulan Februari sampai Maret. Penelitian yang dilakukan adalah penelitian eksperimen semu berbentuk nonequivalent post-test only control group design. Secara lebih jelas, rancangan dari penelitian ini ditunjukkan pada Tabel 2 berikut:

\section{Tabel 2}


Rancangan Penelitian

\begin{tabular}{|ccc|}
\hline Kelas & Perlakuan (treatment) & Post-test \\
\hline Eksperimen & $\mathrm{X}$ & $\mathrm{O}_{2}$ \\
Kontrol & - & $\mathrm{O}_{2}$ \\
\hline
\end{tabular}

(Sumber: Diadaptasi dari Mahendra, 2017)

Populasi dari penelitian ini berjumlah 176 siswa. Langkah pertama yang dilakukan adalah uji keseteraan terhadap populasi yang dilakukan dengan menggunakan nilai dari keterampilan berbicara pada mata pelajaran Bahasa Indonesia. Uji tersebut dilakukan dengan analisis varians satu jalur (ANAVA A). Pada analisis ANAVA A dengan taraf siginifikansi $5 \%$ diperoleh $F_{\text {hitung }}$ sebesar 1,7 dan $F_{\text {tabel }}$ sebesar 2,27. Dengan demikian maka $\mathrm{F}_{\text {hitung }}<\mathrm{F}_{\text {tabel }}(1,7<2,27)$ yang menunjukkan bahwa $\mathrm{H}_{0}$ diterima dan $\mathrm{H}_{1}$ ditolak. Maka dari itu, dapat disimpulkan bahwa tidak terdapat perbedaan yang signifikan pada nilai-nilai keterampilan berbicara dari siswa kelas IV. Teknik random sampling digunakan untuk proses pengambilan sampel secara acak dan sistem yang digunakan adalah sistem undian dengan kertas yang digulung, kemudian dikocok untuk dipilih dua gulungan kertas secara acak. Dari hasil undian tersebut, terpilih dua sekolah sebagai kelompok eksperimen yang berjumlah 40 siswa dan kelompok kontrol yang berjumlah 36 .

Variabel yang digunakan yaitu variabel independen (bebas) dan variabel dependen (terikat). Variabel bebas yang ditentukan adalah yaitu model pembelajaran kooperatif tipe jigsaw berbantuan mind mapping yang diterapkan pada kelompok eksperimen, sedangkan variabel terikatnya adalah keterampilan berbicara siswa.

Teknik unjuk kerja merupakan salah satu teknik dari metode pengumpulan data non tes. Peneliti memilih metode dan teknik tersebut sebagai cara untuk mengumpulkan data dalam penelitian ini. Untuk mengumpulkan data nilai keterampilan berbicara siswa, digunakan teknik unjuk kerja menggunakan instrumen penilaian jenis skala penilaian (rating scale) dengan menentukan indikator yang mencerminkan keterampilan berbicara. Indikator yang mencerminkan keterampilan berbicara adalah pelafalan, intonasi, struktur kalimat, dan kelancaran berbicara siswa.

Analisis data pada penelitian ini dilakukan setelah pemberian post test kepada siswa kelompok eksperimen dan kelompok kontrol. Data tersebut dianalisis dengan menggunakan statistik deskriptif dan inferensial. Deskripsi data pada statistik deskriptif yang digunakan adalah termasuk di dalamnya mean (M), median (Me), Modus (Mo), standar deviasi, dan varians. Sedangkan pada statistik inferensial digunakan analisis uji-t dengan rumus polled varians untuk menguji hipotesis. Uji hipotesis dilakukan setelah data tersebut memenuhi uji prasyarat berupa uji normalitas dan uji homogenitas varians. Uji normalitas dilakukan menggunakan rumus Chi-kuadrat sedangkan uji homogenitas dengan menggunakan uji $F$ untuk mengetahui homogenitas dari varian data kedua kelompok tersebut.

\section{Hasil dan Pembahasan}

Penelitian ini menghasilkan data berupa data nilai keterampilan berbicara siswa yang merupakan nilai dari hasil post test. Sebanyak 40 siswa dari kelompok eksperiman yang ikut dalam post test, diketahui nilai tertinggi yang diperoleh adalah 95 dan terendah adalah 65 . Di sisi lain, kelompok kontrol dengan anggota 36 siswa mendapatkan nilai tertinggi dan terendah sebesar 90 dan 60 secara berurutan dalam post test yang dilakukan. Secara lebih jelas, data nilai keterampilan berbicara yang diperoleh dapat ditunjukkan pada Tabel. 3 berikut:

Tabel 3

Deskripsi Data Keterampilan Berbicara 


\begin{tabular}{|ccc|}
\hline Hasil Analisis & Kelompok Eksperimen & Kelompok Kontrol \\
\hline Mean & 80,5 & 75,14 \\
\hline Median & 81,77 & 77,27 \\
\hline Modus & 83,94 & 77,83 \\
\hline Standar Deviasi & 7,99 & 7,69 \\
\hline Varians & 63,85 & 59,27 \\
\hline
\end{tabular}

Nilai mean, median, modus keterampilan berbicara siswa disajikan ke dalam kurva polygon untuk menafsirkan sebaran data keterampilan berbicara siswa.

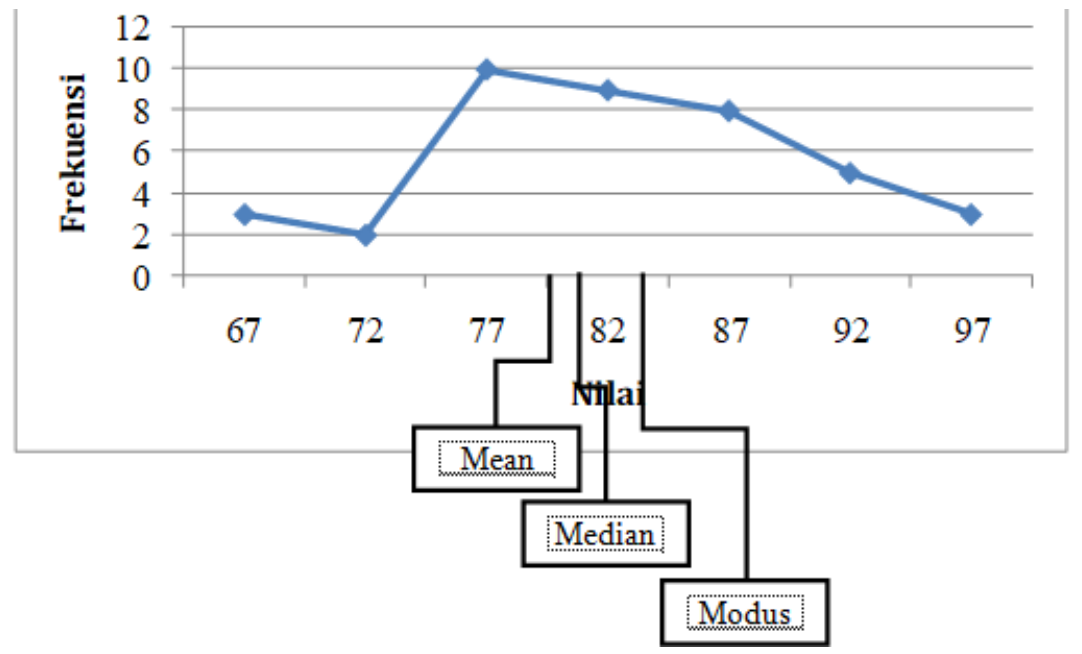

Gambar 1. Grafik Polygon Data Keterampilan Berbicara Kelompok Eksperimen

Kurva polygon pada Gambar 1 menunjukkan nilai mean, median, dan modus dari kelompok eksperimen, dari kurva tersebut terlihat bahwa kurva sebaran data keterampilan berbicara pada kelompok eksperimen menunjukkan kurva juling negatif karena nilai modus lebih besar dari median dan mean. Sehingga, sebagian besar nilai yang diperoleh oleh siswa pada kelompok eksperimen cenderung tinggi. Jika dikonversikan ke dalam PAP skala lima, maka keterampilan berbicara siswa anggota dari kelompok eksperimen masuk dalam kriteria sangat tinggi.

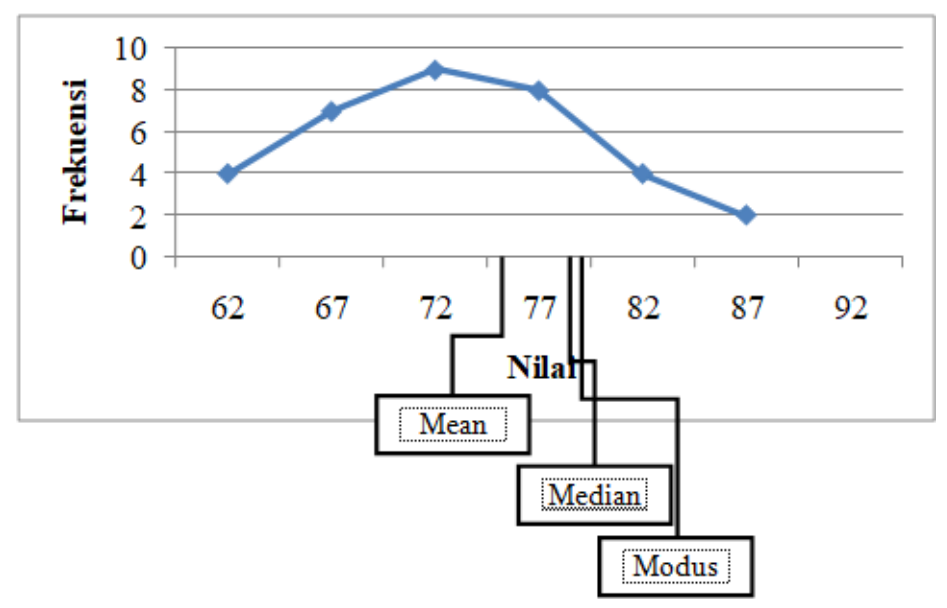

Gambar 2. Grafik Polygon Data Keterampilan Berbicara Kelompok Kontrol

Pada Gambar 2, dapat dilihat kurva polygon dengan nilai mean, median, dan modus yang digambarkan dari kelompok kontrol, terlihat bahwa kurva sebaran data dari 
keterampilan berbicara siswa pada kelompok kontrol menunjukkan kurva juling negatif karena nilai modus lebih besar dari nilai median dan mean. Jadi dapat disimpulkan bahwa sebagian besar nilai yang diperoleh oleh siswa pada kelompok kontrol cenderung tinggi. Jika dikonversikan ke dalam PAP skala lima, maka keterampilan berbicara siswa pada kelompok kontrol tergolong dalam kategori tinggi. Hasil data keterampilan berbicara kelompok eksperimen dan kelompok kontrol, diperoleh hasil kelompok eksperimen memiliki nilai ratarata yang lebih tinggi dibandingkan kelompok kontrol.

Uji selanjutnya yang dilakukan adalah uji prasyarat, yaitu uji normalitas dari sebaran data dan uji homogenitas varians. Dari hasil uji normalitas pada kelompok eksperimen, diperoleh nilai $X^{2}$ hitung $=5,78<X^{2}$ tabel $=14,067$ dengan taraf signifikansi $5 \%$ dan dk $=8-1=$ 7. Nilai tersebut menunjukkan bahwa $\mathrm{H}_{0}$ diterima, dapat disimpulkan bahwa sebaran data nilai post-test keterampilan berbicara dari kelompok eksperimen memiliki distribusi yang normal. Di sisi lain, hasil uji normalitas pada kelompok kontrol menunjukan hasil dengan nilai $X^{2}{ }_{\text {hitung }}=2,84<X^{2}{ }_{\text {tabel }}=14,067$ pada taraf signifikansi $5 \%$ dan $\mathrm{dk}=8-1=7$. Nilai tersebut menandakan bahwa $\mathrm{H}_{0}$ diterima, jadi sebaran data pada nilai kelompok kontrol juga memiliki distribusi yang normal. Selanjutnya adalah uji homogenitas yang dilakukan pada kedua kelompok dengan menggunakan Uji F. Dari hasil uji homogenitas tersebut diperoleh nilai $F_{\text {hitung }}=1,077$ dan $F_{\text {tabel }}=3,98$ dengan taraf signifikansi $5 \%$ atau dapat dilihat bahwa nilai $F_{\text {hitung }}<F_{\text {tabel }}$ yang menunjukkan simpulan bahwa tidak terdapat perbedaan varians antara kelompok eksperimen dan kelompok kontrol (varians data homogen).

Setelah dilakukan uji prasyarat, kemudian dilakukan analisis uji hipotesis menggunakan uji-t dengan rumus polled varians. Hasil analisis data uji-t, diperoleh nilai thitung adalah 2,971 dan nilai $t_{\text {tabel }}$ adalah 1,6657 pada taraf signifikansi 5\%. Dari hasil tersebut dapat dilihat bahwa nilai $t_{\text {hitung }}>t_{\text {tabel }}$ maka $\mathrm{H}_{1}$ diterima jadi, dapat ditarik simpulan bahwa terdapat pengaruh yang signifikan model pembelajaran kooperatif tipe jigsaw berbantuan mind mapping terhadap keterampilan berbicara siswa kelas IV. Implementasi model pembelajaran kooperatif tipe jigsaw berbantuan mind mapping mampu membantu siswa melatih dan mengembangkan keterampilan berbicara melalui langkah-langkah yang sistematis.

Langkah pertama adalah persiapan. Dalam langkah persiapan, guru memotivasi siswa sekaligus menyampaikan tujuan pada pembelajaran. Kegiatan ini lebih didominasikan dengan kegiatan diskusi yang lebih menekankan pemberian pertanyaan untuk siswa mengenai tujuan pembelajaran. Sehingga siswa dapat berlatih berkomunikasi secara lisan dengan baik. Selain itu, guru memberikan motivasi agar siswa aktif mengikuti kegiatan pembelajaran. Jika siswa aktif dalam kegiatan pembelajaran, baik aktif berdiskusi dengan sesama teman maupun aktif bertanya kepada guru maka secara tidak langsung siswa mampu berkomunikasi secara lisan dan hal tersebut dapat melatih keterampilan berbicara siswa. Hal tersebut sejalan dengan pendapat Ningrat \& Sumantri (2018) yang menyatakan bahwa motivasi belajar adalah dorongan dari dalam dan luar diri siswa untuk memiliki keinginan belajar tanpa adanya paksaan agar dapat terjadinya perubahan tingkah laku untuk mencapai tujuan yang dingin dicapai. Jika keinginan siswa untuk belajar sangatlah besar, maka besar pula tingkat keaktifannya dalam pembelajaran. Hal tersebut dapat mengembangkan keterampilan berbicara siswa.

Langkah kedua adalah penyajian informasi. Siswa menyimak guru menyampaikan fakta-fakta yang berkaitan dengan materi pembelajaran. Saat menyimak, siswa mendengarkan kalimat-kalimat yang disampaikan guru, kegiatan tersebut telah memberikan pengalaman kepada siswa mengenai indikator keterampilan berbicara yaitu struktur kalimat dan pelafalan. Dengan demikian siswa mampu mengembangkan keterampilan berbicaranya. Kegiatan tersebut sejalan dengan pendapat Hasanah, dkk. (2019) yang mengungkapkan bahwa melakukan kegiatan menyimak dapat menstimulasi siswa agar mampu berkomunikasi dengan baik. Hal tersebut juga sesuai dengan pendapat Arianto (2018) yang menyatakan bahwa keterampilan menyimak dan berbicara merupakan keterampilan yang saling melengkapi dan berpadu menjadi komunikasi lisan. Saat siswa menyimak, guru juga merangsang siswa secara positif melalui pemberian pertanyaan-pertanyaan yang mendorong siswa untuk menjawab secara lisan. Kegiatan tersebut juga dapat melatih 
keterampilan berbicara siswa karena siswa terus mendapat kesempatan untuk berkomunikasi lisan, baik dengan teman maupun dengan guru.

Langkah ketiga adalah membentuk kelompok asal. Saat langkah ini diterapkan siswa menyimak guru membagikan sub materi yang berbeda (tokoh antagonis, tokoh protagonis, tokoh utama, dan tokoh tambahan). Sama halnya dengan langkah kedua, saat langkah ketiga siswa juga mendapat kesempatan untuk menambah wawasan melalui kegiatan menyimak. Hal tersebut sesuai dengan pendapat Sari (2019) yang menyatakan bahwa melalui kegiatan menyimak memungkinkan siswa dapat lancar berkomunikasi dan memiliki informasi atau wawasan baru. Nampak saat proses pembelajaran berlangsung, terdapat siswa yang bertanya kepada guru mengenai pembagian materi saat di kelompok asal. Hal tersebut mengacu pada rasa antusias siswa dalam pembelajaran. Saat siswa memiliki rasa antusias terhadap suatu materi pembelajaran, hal tersebut dapat mendorong siswa untuk terus aktif bertanya dan menyampaikan ide atau pemikirannya mengenai materi tersebut. Kegiatan ini dapat melatih keterampilan berbicara siswa.

Langkah keempat adalah pembentukan kelompok ahli. Siswa yang mendapat sub materi yang sama, berkumpul membentuk kelompok baru yang dinamakan kelompok ahli. Kemudian dilanjutkan dengan langkah kelima, yaitu diskusi kelompok ahli. Diskusi adalah proses dua atau lebih siswa yang berinteraksi secara verbal mengenai tujuan yang sudah ditentukan melalui tukar menukar informasi (Herlina, 2020). Dengan adanya kegiatan diskusi kelompok ahli dapat mendorong siswa untuk berlatih berkomunikasi atau berbicara dengan sesama temannya. Saat diskusi kelompok ahli, semua siswa aktif dalam berbicara mengemukakan pendapat, saling memberikan informasi terkait dengan materi yang dibahas hingga tercapainya tujuan setiap kelompok untuk memahami materi yang dibahas dalam kelompok ahli. Dengan demikian, semua siswa mampu melatih keterampilan berbicaranya.

Langkah keenam ialah diskusi dalam kelompok asal. Semua siswa berkumpul bersama anggota kelompok asalnya untuk mendiskusikan hasil temuan atau hasil diskusi di kelompok ahli dengan membuat mind mapping. Terlihat dari pembelajaran yang telah dilaksanakan oleh peneliti, semua siswa bergantian menjelaskan hasil diskusi kelompok ahli hingga seluruh anggota kelompok memahami keseluruhan materi yang dibahas dan dilanjutkan dengan pembuatan mind mapping. Mengacu pada kegiatan tersebut, dapat melatih tanggung jawab siswa yang sejalan dengan kelebihan dari model kooperatif tipe jigsaw yang dikemukakan oleh Trisianawati, dkk. (2016), yaitu siswa memiliki tanggung jawab secara individual. Selain itu, kegiatan diskusi kelompok asal mampu mengembangkan kemampuan berbicara siswa karena siswa dituntut untuk bisa mentransfer materi kepada temannya agar semua anggota kelompok mengerti mengenai materi tersebut. Kegiatan berdiskusi, baik diskusi pada kelompok asal maupun diskusi pada kelompok ahli mampu mengembangkan indikator keterampilan berbicara yaitu pelafalan, struktur kalimat dan kelancaran saat siswa berbicara.

Langkah ketujuh adalah presentasi. Pada langkah ini semua siswa secara bergantian ke depan kelas mempresentasikan mind mapping yang dibuat pada langkah keenam. Presentasi ini bertujuan untuk meningkatkan semua indikator keterampilan berbicara yaitu kelancaran, pelafalan, intonasi, dan struktur kalimat yang disampaikan siswa sehingga siswa memiliki keterampilan berbicara yang lebih baik dari sebelumnya. Nampak pada saat presentasi siswa mampu menguasai materi yang disampaikan dengan bantuan mind mapping. Kegiatan presentasi dapat melatih keterampilan berbicara siswa, hal tersebut didukung oleh Sulistyowati (2018) yang menyatakan bahwa presentasi ialah aktivitas komunikasi secara lisan mengenai hasil pemikiran dengan suatu tujuan. Saat siswa melakukan presentasi, terlihat guru melakukan penilaian keterampilan berbicara secara objektif, karena saat presentasi semua indikator keterampilan berbicara mudah untuk dinilai.

Langkah kedelapan adalah evaluasi. Pada langkah ini semua siswa kembali pada tempat duduknya untuk menyelesaikan tes evaluasi secara perseorangan. Kita dapat mengetahui seberapa jauh pemahaman siswa melalui kegiatan evaluasi. Saat evaluasi 
berlangsung, keadaan siswa sangat tenang mengerjakan tes. Hal tersebut menandakan siswa mampu mengerjakan tes evaluasi sehingga hasilnya tercapai dengan baik. Hasil tes evaluasi siswa menunjukkan hasil yang baik dan mengalami peningkatan. Mengacu pada hal tersebut, mampu membantu siswa dalam mengembangkan keterampilan berbicara. Hal ini sejalan dengan pendapat Halimah \& Sukmayadi (2019) yang menyatakan bahwa peningkatan pemahaman tentang pengetahuan dapat membantu siswa dalam meningkatkan komunikasinya.

Selanjutnya langkah kesembilan adalah penutup yang didominasi dengan kegiatan pemberian apresiasi. Apresiasi diperuntukkan untuk siswa-siswa yang aktif dan bersemangat saat mengikuti proses pembelajaran. Terdapat berbagai macam apresiasi yang dapat diberikan kepada siswa tersebut, salah satunya adalah dengan memberikan tepuk tangan yang keras dari seluruh anggota kelas lainnya dan juga berupa penambahan nilai kepada siswa yang telah aktif dalam proses pembelajaran tersebut. Pemberian apresiasi tersebut dilakukan agar siswa termotivasi untuk aktif dalam kegiatan pembelajaran selanjutnya.

Berdasarkan temuan-temuan pada penelitian ini, diketahui perbedaan pembelajaran yang menerapkan model pembelajaran kooperatif tipe jigsaw berbantuan mind mapping dan kegiatan pembelajaran yang tidak menerapkan model tersebut tentu memberikan dampak yang berbeda pada keterampilan berbicara siswa. Temuan tersebut berkaitan dengan hasil penelitian relevan yang dilakukan oleh Nahgiyah \& Relmasira (2019) yang menunjukkan penerapan model cooperative learning tipe jigsaw dapat memberikan dukungan untuk meningkatkan keterampilan berbicara siswa kelas IV yang ditunjukkan dengan semua siswa mengikuti proses belajar mengajar serta melaksanakan tugas secara aktif, serta dapat secara aktif juga terlibat dalam proses penyelesaian masalah, sehingga siswa sudah berani dan percaya diri untuk aktif saat proses belajar mengajar. Hasil penelitian yang dilakukan oleh Nahgiyah \& Relmasira (2019) berkaitan erat dengan hasil penelitian penulis, kaitannya yakni model pembelajaran jigsaw mempengaruhi keterampilan berbicara siswa kelas IV. Selain itu, hasil penelitian dari Musyawir \& Mangesa (2016) juga memperkuat hasil penelitian ini, ditunjukkan dengan hasil penelitian tentang keterampilan berbicara siswa yang dibelajarkan dengan model active learning teknik jigsaw mengalami peningkatan lebih tinggi daripada siswa yang ikut dalam proses belajar mengajar dengan metode konvensional. Hasil penelitian yang dilakukan oleh Musyawir \& Mangesa (2016) juga berkaitan dengan hasil penelitian penulis yang membuktikan model pembelajaran jigsaw berpengaruh dalam meningkatkan keterampilan berbicara siswa. Keunggulan penelitian ini dibandingkan dengan penelitian-penelitian sebelumnya adalah pada penelitian ini menggunakan media mind mapping untuk merangsang siswa berbicara. Karena dengan penggunaan mind mapping yang memuat gambar-gambar, mampu menuntun siswa untuk mengeluarkan idea atau pemikirannya melalui berbicara.

\section{Simpulan}

Dari hasil uji hipotesis serta pembahasan yang telah dilakukan, dapat ditarik simpulan bahwa model pembelajaran kooperatif tipe jigsaw berbantuan mind mapping memiliki pengaruh yang nyata terhadap keterampilan berbicara siswa kelas IV. Berdasarkan temuan-temuan pada penelitian ini, dapat disampaikan saran-saran sebagai berikut. (1) Diharapkan siswa dapat mengikuti proses belajar mengajar dengan lebih aktif dan dapat meningkatkan pengetahuan yang dimiliki dengan cara membangun sendiri pengetahuan tersebut dengan menggunakan kesempatan yang diberikan oleh guru untuk berpartisipasi saat kegiatan pembelajaran menggunakan model pembelajaran kooperatif tipe jigsaw berbantuan mind mapping berlangsung. Selanjutnya, diharapkan juga siswa dapat lebih percaya diri saat berkomunikasi dan meningkatkan kreativitas serta motivasi untuk belajar. (2) Pengajar atau guru diharapkan dapat merancang proses pembelajaran yang lebih kreatif, sehingga dapat memberikan tempat belajar yang lebih baik dengan meningkatkan fasilitas berupa sumber belajar dan kesempatan yang lebih banyak untuk siswa agar dapat lebih aktif dalam proses belajar mengajar melalui model pembelajaran 
kooperatif tipe jigsaw berbantuan mind mapping agar tercipta suasana belajar yang menarik dan menyenangkan khususnya dalam materi keterampilan berbicara. (3) Kepala sekolah disarankan agar ikut memperkenalkan dan memberi dorongan untuk guru agar dapat menerapkan model pembelajaran yang inovatif khususnya model pembelajaran kooperatif tipe jgsaw berbantuan mind mapping dalam upaya untuk meningkatkan keterampilan berbicara siswa. (4) Peneliti lain agar menggunakan hasil penelitian ini sebagai referensi dalam melakukan penelitian selanjutnya pada tema dan kegiatan pembelajaran lainnya untuk memperoleh hasil yang lebih baik.

\section{Daftar Pustaka}

Peraturan Menteri Pendidikan dan Kebudayaan Republik Indonesia Nomor 67 Tahun 2013 Tentang Kerangka Dasar dan Struktur Kurikulum Sekolah Dasar/ Madrasah Ibtidaiyah. Jakarta: Menteri Pendidikan dan Kebudayaan Republik Indonesia.

Aprinawati, I. (2017). Penggunaan Media Gambar Seri Untuk Meningkatkan Kemampuan Berbicara Anak Usia Dini. Jurnal Obsesi : Jurnal Pendidikan Anak Usia Dini, 1(1), 72.

Arianto. (2018). Penerapan Model Pembelajaran Terpadu Untuk Meningkatkan Keterampilan Menyimak dan Berbicara Siswa Kelas Ix-2 Smpn 17 Kendari. Al-Izzah: Jurnal HasilHasil Penelitian, 13(1), 48.

Halimah, L., \& Sukmayadi, V. (2019). The Role of Jigsaw Method in Enhancing Indonesian Prospective Teachers Pedagogical Knowledge and Communication Skill. International Journal of Instruction, 12(2), 289-304.

Hambali. (2017). Cooperatif Learning sebagai Upaya Membangkitkan Kembali Extinction Motivasi Belajar. 01(01), 13-24.

Harsini. (2017). Pengelolaan Pembelajaran dengan Menerapkan Metode Bermain Peran untuk Meningkatkan Keterampilan Berbicara Siswa Kelas IV SD. Manajer Pendidikan, 11(1).

Hasanah, N., Ishartiwi, \& Hayati, N. (2019). Meningkatkan Kemampuan Menyimak Cerita Menggunakan Media Bulletin Board pada Anak Kelompok B di TK Negeri Pembina Yogyakarta. Journal of Primary Education, 1(2), 124-133.

Herlina, E. (2020). Penggunaan Metode Diskusi Kelompok Terbimbing dalam Upaya Meningkatkan Hasil Belajar Geografi pada Siswa SMAN 1 Cisarua Kabupaten Bandung Barat. Universal Journal of Educational Research, 1(1), 1-11.

Indriani. (2019). Mendikbud: Hasil PISA tunjukkan perspektif pendidikan Indonesia. Antaranews.Com. https://www.antaranews.com/berita/1191792/mendikbud-hasil-pisatunjukkan-perspektif-pendidikan-indonesia

Irianto, P. O., \& Febrianti, L. Y. (2017). Pentingnya Penguasaan Literasi bagi Generasi Muda dalam Menghadapi MEA. Proceedings Education and Language International Conference, 1, 640-647.

Kamaruddin, S., \& Yusoff, N. M. R. N. (2019). The Effectiveness of Cooperative Learning Model Jigsaw and Team Games Tournament (TGT) towards Social Skills. Creative Education, 10(12), 2529-2539.

Karacop, A. (2017). The Effects of Using Jigsaw Method Based on Cooperative Learning Model in the Undergraduate Science Laboratory Practices. Universal Journal of Educational Research, 5(3), 420-434.

Kartika, Ni Made, D., Margunayasa, I. G., \& Wibawa, I. M. C. (2017). Pengaruh Model Pembelajaran Inkuiri Terbimbing Berbantuan Peta Pikiran dan Motivasi Berprestasi terhadap Hasil Belajar IPA. MIMBAR PGSD, 5(2). 
Kurniasih, I., \& Sani, B. (2014). Sukses Mengimplementasikan Kurikulum 2013. In Jakarta: Kata Pena. Kata Pena.

Mahendra, I. W. E. (2017). Mengembangkan Kemampuan Research dalam Menghadapi Era SDGs. Seminar Nasional Mengembangkan Kemampuan Research Dalam Menghadapi SDGs.

Mahendra, I. W. Ek. (2019). Pembelajaran dan Asesmen di Era Revolusi Industri 4.0. Seminar Nasional Pada FPMIPA IKIP Saraswati Tabanan.

Munawaroh, S., Suratmat, \& Fathani, A. H. (2019). Kemampuan Penalaran Dan Pemecahan Masalah Matematis Melalui Model Pembelajaran (Air) Menggunakan Media Mind Mapping Pada Materi Bilangan Bulat Kelas Vii Smp Shalahuddin Malang. Pendidikan Matematika, 14(8), 91-99.

Munte, B. (2019). The Effect of Cooperative Model "Jigsaw Type" in Improving Students' Achievement at Christian Education Subject Case: Grade XII IPA 1-2 SMA Negeri 1 Tebing Syahbandar. International Journal of English Literature and Social Sciences, $4(2), 344-350$.

Musyawir, \& Mangesa, R. (2016). Pengaruh Model Active Learning Teknik Jigsaw terhadap Keterampilan Berbicara Efektif Siswa Kelas VII SMP/MTs Se-Kecamatan Namlea Kabupaten Buru. Jurnal Pendidikan Bahasa Dan Sastra Indonesia, 6(2), 44-59.

Nahgiyah, E., \& Relmasira, S. C. (2019). Upaya Peningkatan Keterampilan Berbicara dan Hasil Belajar Melalui Model Pembelajaran Cooperative Learning Tipe Jigsaw. Journal of Education Action Research, 3(3), 201.

Ningrat, S. P., \& Sumantri, M. (2018). Kontribusi Gaya Belajar dan Motivasi Belajar Terhadap Hasil Belajar Bahasa Indonesia. Jurnal IImiah Sekolah Dasar, 2(3), 257.

Nugraha, Purnamasari, I., \& Tanuatmodjo, H. (2016). Interaction Between the Type of School and Learning Outcomes in Student's Soft Skills Enhancement through Cooperative Learning Model (Quasi Experiment on Vocational Students in Bandung). Procedia - Social and Behavioral Sciences, 219, 838-845.

Rezeki, N., Syahrial, \& Surya, Y. F. (2019). Peningkatan Keterampilan Berbicara dengan Menggunakan Model Pembelajaran Kooperatif Think Pair Share. 36(12), 57-74.

Sari, D. P. (2019). Meningkatkan Kemampuan Menyimak dan Berbicara melalui Metode Bercerita dengan Bantuan Media Audio. Journal on Early Childhood Education Research (JOECHER), 1(1), 21-31.

Sari, P. A. P. (2020). Hubungan Literasi Baca Tulis Dan Minat Membaca Dengan Hasil Belajar Bahasa Indonesia. Journal for Lesson and Learning Studies, 3(1), 141-152.

Satriani, N., Soendari, T., \& Warnandi, N. (2019). Pengembangan Program Literasi untuk Meningkatkan Kemampuan Berbicara dan Membaca Anak dengan Hambatan Pendengaran. International Conference on Special Education in Southeast Asia Region (ICSAR) 9th, 124.

Septiana, T. I., \& Ibrohim, B. (2020). Berbagai Kegiatan Membaca untuk Memicu Budaya Literasi di Sekolah Dasar. Jurnal Keilmuan Dan Kependidikan Dasar, 12(01), 41-54.

Sulistyaningrum, H., Winata, A., \& Cacik, S. (2019). Analisis Kemampuan Awal 21st Century Skills Mahasiswa Calon Guru SD. Jurnal Pendidikan Dasar Nusantara, 5(1), 142.

Sulistyowati, W. (2018). Peningkatan Hasil Belajar Berbicara Teks Prosedur Melalui Metode Presentasi Power Point Mata Pelajaran Bahasa Inggris Pada Peserta Didik Kelas IX G Semester 1Tahun Pelajaran 2017 / 2018 SMP Negeri 1 Tugu. BRIGHT: A Journal of English Language Teaching, Linguistics and Literature, 2(1), 79-100.

Trisianawati, E., Djufin, T., \& Setiawan, R. (2016). Pengaruh Model Pembelajaran Kooperatif 
Tipe jigsaw terhadap Hasil Belajar Siswa pada Materi Vektor di Kelas X SMA Negeri 1 Sanggau Ledo. Jurnal Pendidikan Fisika Dan Aplikasinya (JPFA), 06(02), 51-60. 